\title{
Traumatic chiasmal syndrome. Case report
}

\author{
Síndrome quiasmática traumática. Relato de caso
}

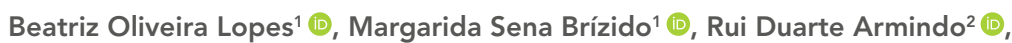
Vanessa Brito Silva ${ }^{3}$ (D), Susana Morais Pina' ${ }^{1}$, Filipe Simões Silva1 ${ }^{1}$

Department of Ophthalmology, Hospital Beatriz Ângelo, Loures, Lisbon, Portugal. 2 Department of Neuroradiology, Hospital Beatriz Ângelo, Loures, Lisbon, Portugal. ${ }^{3}$ Department of Neurology, Hospital Beatriz Ângelo, Loures, Lisbon, Portugal.

How to cite:

Lopes BO, Brízido MS, Armindo RD, Silva VB, Pina SM, Silva FS. Traumatic chiasmal syndrome. Case report. Rev Bras Oftalmol. 2021;80(5):e0033.

https://doi.org/10.37039/1982.8551.20210033

Keywords:

Optic chiasm; Hemianopsia;

Craniocerebral trauma;

Magnetic resonance imaging

Descritores:

Quiasma óptico; Hemianopsia;

Traumatismos craniocerebrais;

Imagem por ressonância magnética

Received on: March 03, 2021

Accepted on: June 26, 2021

Corresponding author: Beatriz Nunes de Oliveira Lopes Av. Carlos Teixeira n³, 2674-514 Loures E-mail: beatriz.oliveira.lopes@

hbeatrizangelo.pt

Institution: Department of Ophthalmology, Hospital Beatriz Ângelo, Loures, Lisboa, Portugal

Conflict of interest: the authors declare no conflict of interest.

Financial support: the authors received no financial support for this work.

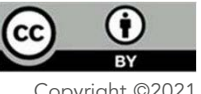

Copyright (C)2021

\section{ABSTRACT}

Traumatic chiasmal syndrome is one of the rare etiologies of chiasmal syndrome, characterized by optic chiasm injury following head trauma. The main visual defect associated is bitemporal hemianopia with macular splitting; however, it can present with a variety of other visual defects and neurologic signs. The authors report a case of complete bitemporal hemianopia after head trauma, with multiple frontal and skull base fractures and no other neurologic deficits, or hypothalamic-pituitary abnormality. Most cases of traumatic chiasmal syndrome are caused by mechanical stretch or compression of the chiasma. Nevertheless, in this case, the radiologic findings excluded macroscopic disruption or external compression of the chiasma, raising the possibility of a contusion necrosis associated with functional impairment of the optic chiasma. Traumatic chiasmal syndrome must be considered in the differential diagnosis of patients presenting with complete bitemporal hemianopia after head injury caused by frontal and skull base fracture.

\section{RESUMO}

A síndrome quiasmática traumática é uma das raras etiologias da síndrome do quiasma óptico, que se caracteriza pela presença de lesão do quiasma óptico causada por traumatismo craniencefálico. O principal defeito visual associado é a hemianopsia bitemporal com macular splitting. No entanto, pode se manifestar por uma variedade de outros defeitos visuais e sinais neurológicos. Os autores relatam um caso de hemianopsia bitemporal completa após traumatismo craniencefálico com múltiplas fraturas frontais e da base do crânio na ausência de outros défices neurológicos ou alterações do eixo hipotálamo-hipofisário. A maioria dos casos de síndrome quiasmática traumática é causada por estiramento mecânico ou compressão do quiasma. No entanto, no caso apresentado, os achados radiológicos excluíram lesão macroscópica ou compressiva do quiasma, levantando a possibilidade de uma necrose após contusão associada ao compromisso funcional do quiasma óptico. A síndrome quiasmática traumática deve ser considerada no diagnóstico diferencial de doentes que apresentam hemianopsia bitemporal completa após traumatismo craniencefálico, especialmente em casos de fratura do osso frontal e da base do crânio. 


\section{INTRODUCTION}

Traumatic chiasmal syndrome (TCS) occurs due to an injury at the level of crossing fibers in the optic chiasma following head trauma. It is considered a rare entity since only severe impact can damage this anatomically privileged structure, usually in cases with multiple frontal and skull base fractures. . $^{(1)}$

The most common visual field defect observed in these patients is bitemporal hemianopia, explained by the peculiar arrangement of fibers of the optic nerves, although the visual field loss can be of varying degrees. It is also often associated with neurologic deficits or hypothalamic-pituitary abnormalities. ${ }^{(2)}$ Isolated bitemporal hemianopia without accompanying manifestations is not commonly seen in patients with TCS. The current report describes a patient who presented with isolated complete bitemporal visual field deficit in light of TCS.

\section{CASE REPORT}

A 45-year-old female presented to our hospital with a complaint of peripheral vision decreased in both eyes. A road accident 15 years before caused head trauma with multiple fronto-facial and skull base fractures, requiring surgical repair with implantation of metal plate in left malar region at that time. Examination revealed best corrected visual acuity of 20/50 in the right eye and 20/20 in the left eye. Color vision was 17/17 in both eyes. Pupillary examination revealed a right relative afferent pupillary defect. Confrontation visual field revealed a temporal visual field defect in both eyes. Ocular motility testing was full in both eyes but showed a slight esotropia of 8-prism diopter in the right eye, without diplopia, which could be explained by the hemifield slide phenomenon. Intra-ocular pressure was $14 \mathrm{mmHg}$ in the right eye and $13 \mathrm{mmHg}$ in the left eye. Anterior segment examination was unremarkable in both eyes, except for the presence of a slight decrease of left eyelid fissure. Posterior segment examination revealed bilateral optic disc pallor (Figure 1). Visual field test using central 30-2 patter of automated static perimetry showed bitemporal hemianopia (Figure 2).

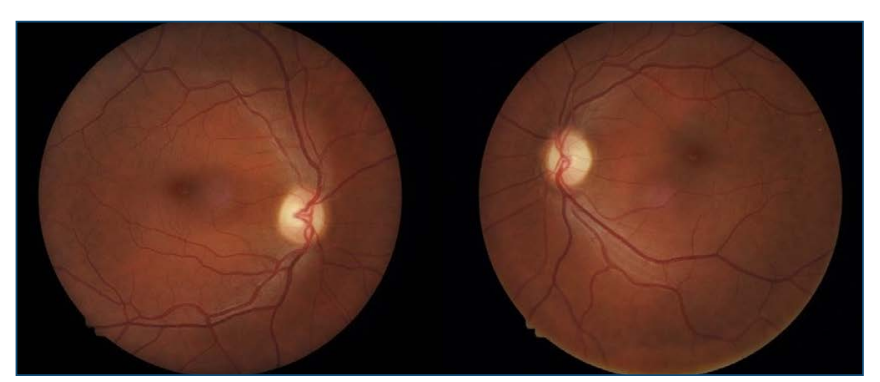

Figure 1. Image of ocular fundus showing bilateral optic disc pallor.
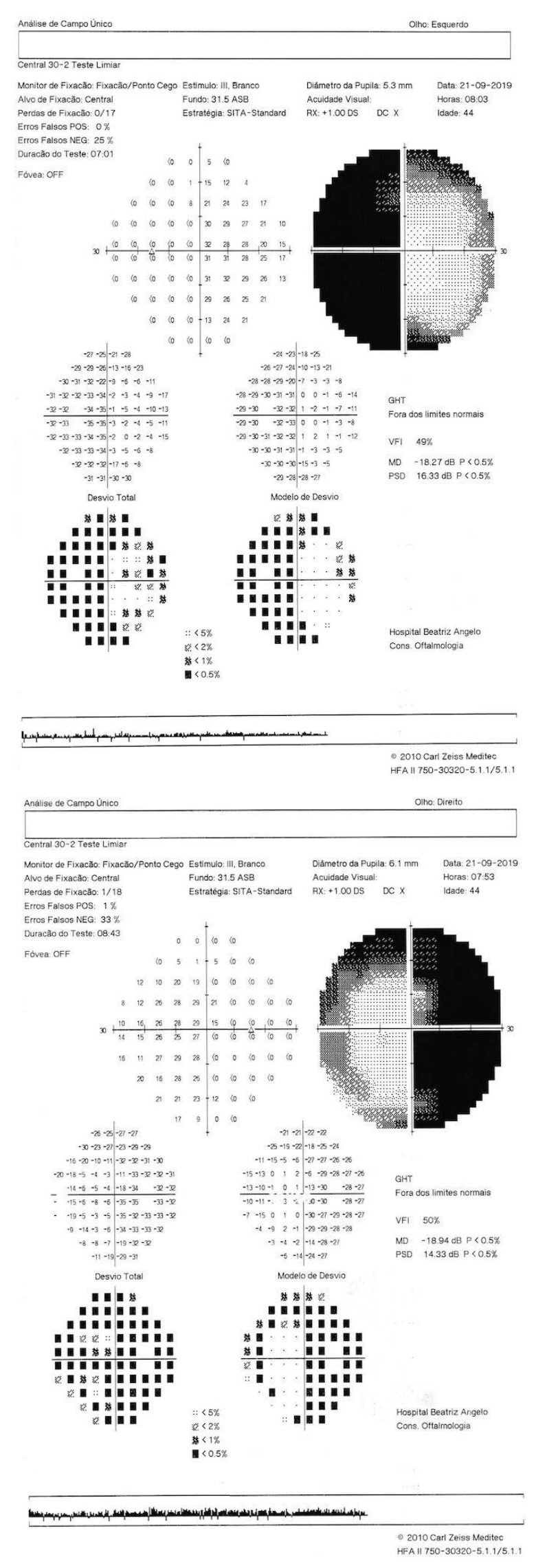

Figure 2. Automated static perimetry showing bitemporal hemianopia using central 30-2 patter. 


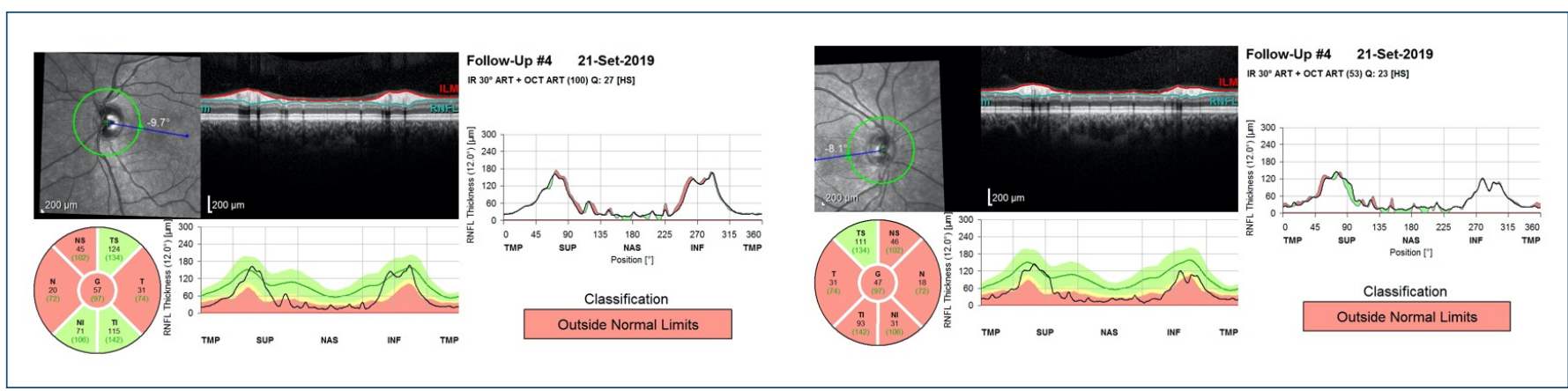

Figure 3. Optical coherence tomography showed reduced thickness in the retinal nerve fiber layer in almost all quadrants in the right eye and in the left eye, particularly in nasal and temporal quadrants, simulating a bow-tie pattern.

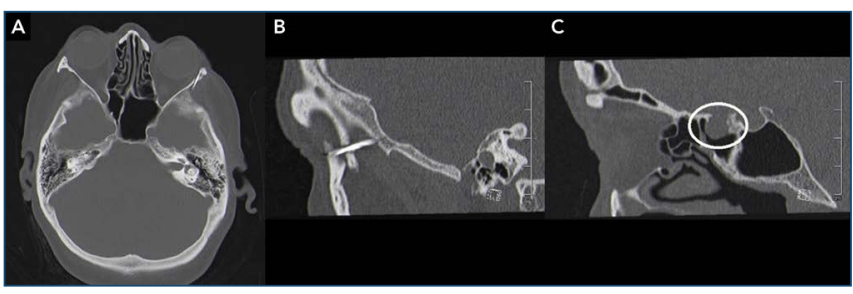

Figure 4. Head and orbits computed tomography (bone window) axial ( $A$ ) and sagittal ( $B$ and $C$ ) images showing signs of surgical repair of the left lateral orbital wall, with additional evidence of posterior ethmoidal roof fracture and associated meningocele (circle in C).

Optical coherence tomography (OCT) showed reduced thickness in the retinal nerve fiber layer primarily in the right eye, affecting almost all quadrants (Figure 3).

Computed tomography of the head, orbits and skull showed sequelae of traumatic injuries of the face and associated bilateral fronto-basal cortico-subcortical lesions (Figures 4 and 5).

Magnetic resonance imaging (MRI) of the brain and orbits was compromised by distortion artifacts induced by the metallic implanted material at the lateral wall of the left orbit, but excluded external compression of the optic chiasma and showed a small area of focal T2 hyperintensity compatible with chiasmal contusion (Figure 6). ${ }^{(2)}$

No focal neurological deficits, including cranial nerve palsy, diabetes insipidus, cerebrospinal fluid rhinorrhea and carotid cavernous fistula were detected. Endocrinology evaluation found no hypothalamic-pituitary abnormality. Clinical findings remained unchanged during a 6-year follow-up.

\section{DISCUSSION}

The optic chiasma is part of the visual pathway where the optic nerves partially cross and the nasal fibers of the retina decussate. The arrangement of fibers at the chiasma is responsible for the typical visual defects frequently observed when this structure is compromised.(1)

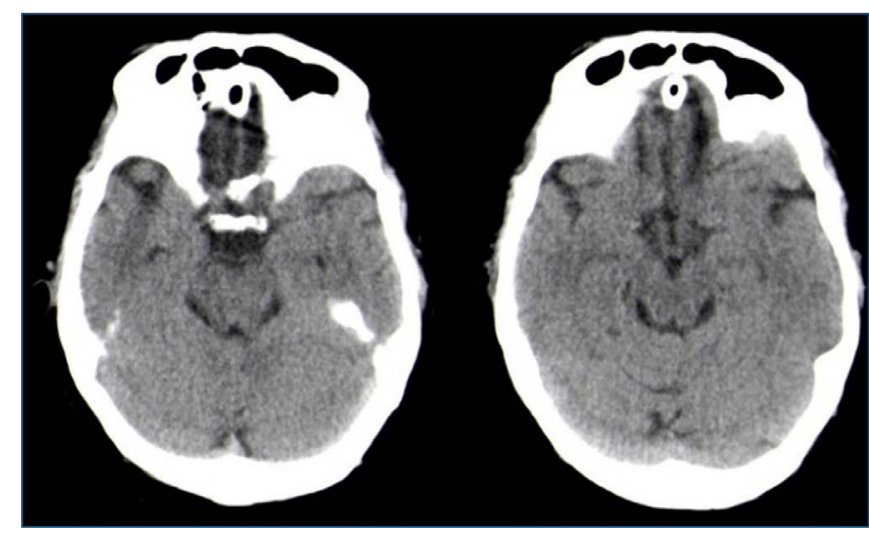

Figure 5. Head computed tomography (parenchymal window). Consecutive axial levels showing sequelae of bilateral inferior frontal contusions.

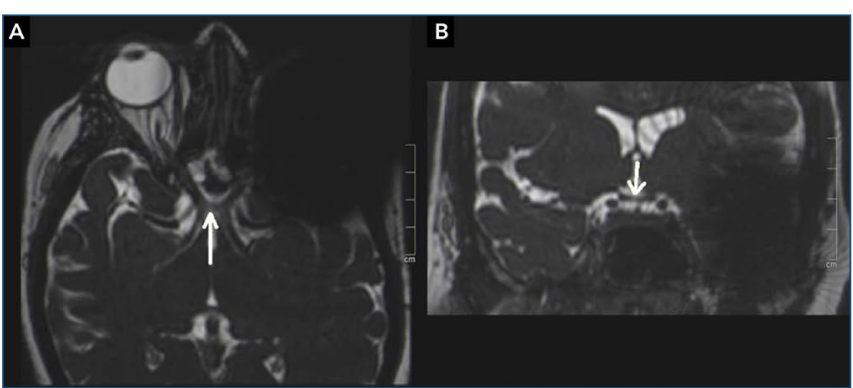

Figure 6. Heavily T2-weighted axial (A) and coronal (B) brain magnetic resonance images evidencing a small area of focal thinning and hyperintensity of chiasmal fibers (arrows).

Optic chiasm involvement mainly occurs by neoplastic compression, such as pituitary adenomas. ${ }^{(1)}$ However, head trauma can affect retrobulbar optic pathways, through intracanalicular segment injury of the optic nerve, resulting in TCS. It is a rare condition, affecting $4.4 \%$ of patients who suffered head trauma. ${ }^{(3)}$ Most reported injuries occur following frontal head trauma, along with multiple skull base fractures in association with traffic accidents or falls. ${ }^{(1)}$ There is no specific pattern of field defects that develop after TCS. Bitemporal field defect, considered the hallmark of chiasmal involvement, is the most common associated visual field defect. ${ }^{(4)}$ TCS may also manifest as either complete 
monocular blindness, temporal hemianopia, quadrantopia or subtle scotomas which may have macular involvement. ${ }^{(1)}$ Other accompanying manifestations may include cranial nerve palsies, carotid cavernous fistula, carotid aneurysm, cerebrospinal fluid rhinorrhea, panhypopituitarism, diabetes insipidus, meningitis, intrasellar hematoma and pneumatocele..$^{(1,5)}$

Complete bitemporal hemianopia with decreased visual acuity in one or two eyes, as seen in this case, occurs in about $85 \%$ of patients, since pre-chiasmal optic pathways are also frequently involved ${ }^{(5)}$. Blurred near vision, reading difficulty and diplopia may also occur with bitemporal visual loss because of hemifield slide phenomenon. ${ }^{(3)}$ Preexisting small or latent strabismus may manifest as well. ${ }^{(3,6)}$ Hemifield slide phenomenon can be explain by the compromise of binocularity with consequent loss of the capability to fuse the visual fields of both eyes. ${ }^{(3)}$ This may cause ocular alignment instability and slight ocular deviations in the absence of muscle paresis. ${ }^{(3,7)}$ Macular splitting commonly seen in hemianopic patients is also reported with chiasmal injury in which the fixation point was compromised, leading to eccentric or unstable fixation..$^{(3,8)}$ The changes in ocular motility seen in our patient could be explained by these phenomena.

The most relevant imaging modality to diagnose TCS is MRI. ${ }^{(1,3)}$ In the current case, radiologic findings excluded macroscopic disruption or external compression of the chiasma, but showed a small area of focal T2 hyperintensity compatible with chiasmal contusion. Several mechanisms have been suggested to explain TCS etiology, such as external compression by brain tissue or hematoma, mechanical stretching, or contusion necrosis, as seen in our patient. ${ }^{(3,5)}$ There are also some reports of a possible compromised blood supply to the central area of the chiasma. Traquair et al. suggested pial vessels responsible for chiasma supply may suffer tearing caused by mechanical stretching, explaining the functional impairment of the optic chiasma in the absence of anatomical disruption. ${ }^{(9)}$
The pathophysiological mechanisms discussed above should not be considered to be mutually exclusive. ${ }^{(2)}$ It is possible that TCS results from the combination of several of these mechanisms.

In respect to diagnosis of TCS, although MRI is an important diagnostic imaging exam, especially in the presence of other neurological deficits, it may not always be performed. Ostri et al. revealed that OCT can also play an important role in the diagnosis of optic chiasma lesion, through non-invasive measurement of the retinal nerve fiber layer thickness. ${ }^{\left({ }^{10}\right)}$ In our opinion, an automated static perimetry could also be particularly useful.

Although rare, head trauma may cause damage of chiasmal crossing nerve fibers resulting in a complete bitemporal hemianopia. TCS must be considered in the differential diagnosis of these patients after a head injury causing frontal and anterior skull base fractures, with or without other associated manifestations. Patients should be under close follow-up to rule out any new neurological signs or symptoms.

\section{REFERENCES}

1. Mookan LV, Thomas PA, Harwani AA. Traumatic chiasmal syndrome: a meta-analysis. Am J Opththalmol. 2018;9:119-23.

2. Vora TK, Ravi RR. Traumatic chiasmal syndrome: a midline axonal injury. Neuro Ophthal. 2015;39(5):253-6.

3. Elnahry AG, Elnahry GA. Clinical and imaging findings one year following traumatic chiasm transection. Neuro Ophthal. 2019;43(3): 205-7.

4. Tang RA, Kramer LA, Schiffman J, Woon C, Hayman LA, Pardo G Chiasmal trauma: clinical and imaging considerations. Surv Ophthalmol. 1994;38(4):381-3.

5. Savino PJ, Glaser JS, Schatz NJ. Traumatic chiasmal syndrome. Neurology. 1980;30(9):63-70.

6. Hassan A, Crompton JL, Sandhu A. Traumatic chiasmal syndrome: a series of 19 patients. Clin Exp Ophthalmol. 2002;30(4):273-80.

7. Peragallo JH, Bialer OY, Pineles SL, Newman NJ. Hemifield slide phenomenon as a result of heteronymous hemianopia. Neuro Ophthal. 2014;38(2):82-7

8. Perenin MT, Vadot E. Macular sparing investigated by means of Haidinger brushes. Br J Ophthalmol. 1981;65(6):429-35.

9. Traquair HM, Dott NM, Russel WR. Traumatic lesions of the chiasma. Brain. 1935;58(3):398-411.

10. Ostri C, Damgaard B, Hamann S. Optical coherence tomography documenting retinal nerve fiber loss in traumatic optic chiasmal syndrome. Acta Ophthalmol. 2012;90(8):792-4 